\title{
Micro Fast Food Outfits Operations and Economic Empowerment of the People (Through Income Generation) in Calabar Urban, Cross River State, Nigeria
}

\author{
Adie, Justine Akunke ${ }^{1 *} \quad$ Beshel, Ignatius Akwagiobe $^{2} \quad$ Ekpe, Osim James $^{1}$ \\ 1.Department of entrepreneurial studies, College of Health Technology, P. M.B. 1324, Calabar-Nigeria \\ 2.Department of Health Information Management, College of Health Technology, P.M.B 1324, Calabar- \\ Nigeria
}

\begin{abstract}
This study examined Micro fast food outfits operations and economic empowerment of the people through income generation in Calabar urban, Cross River State, Nigeria. The specific objectives were identified and related literature were reviewed. Data for this research were derived from a 20 items questionnaire. Survey research design was adopted for the study with 600 respondents randomly selected from Calabar urban. Data generated were presented using simple percentage analysis. The findings of the study revealed that; micro - fast food outfits operations can serve as a source of income generation to people in Calabar urban, Cross River State; micro - fast food outfits operations can serve as a source of business empowerment for the people in Calabar urban, and that, micro - fast food outfits operations relate with economic wellbeing of the people in Calabar urban, Cross River State. The study recommended that Government should create a favourable business atmosphere for fast food outfits and Micro fast food outfits operators should be motivated so that they will understand their role in economic empowerment in the State and Soft loan should be provided to micro fast food operators to enhance their operations and invest on a large scale fast food outfits operations.
\end{abstract}

Keywords: Micro, outfits, operations, economic empowerment, urban dwellers, income generation.

DOI: $10.7176 / \mathrm{JAAS} / 76-01$

Publication date:October $31^{\text {st }} 2021$

\section{Introduction}

The existence of fast food is not new in Cross River State and Nigeria. The history of fast food operations as business entity can be traced to 1500 A.D., at the time of the era of coffee shop. Although the Paris is a renounced birth place of fast food business two centuries ago, but fast food operations had existed long before then. In the past half century, 'there has been a surge in what we now think of as quick service restaurants (QSR), serving a growing number of people who are eating more and more of their meals outside the home", (Kiefer 2002; Walker 2011). Fast food outfits have been in operation for quite some time for most of human civilization, principally to meet the needs of travellers. Although Taverns and coffee houses attracted people for the purpose of sharing beverages in the 17th century, eating outside the home did not receive immense attention in Western society until the late 18th century (Mackenzie \& Chan, 2009). Fast food operation is connected with urbanization. It is associated with the urban culture. Fast food outfits operations and high population density appeared to have developed simultaneously.

Fast food businesses are classified under the hospitality industry. The hospitality industry (fast food inclusive) provides food for people of all ages, in all walks of life and in every situation. The caterer should be able to identify people's hospitality needs and also ensures that customers obtain necessary services ((Fakokunde, 2010). The fast food subsector of the economy is significant in the following ways:

i. Provision of food and drinks - One of the importance of the fast food outfits is the provision of food, drinks etc. to customers.

ii. Revenue mobilization - This is an important contribution to the Nigeria economy. The government generates huge amount of revenue from the activities of fast food outfits operation. Revenue is generated in the form of company tax, registration fees, monthly/quarterly subscription; Value Added Tax (VAT) among others.

iii. Income generation - services offered by fast food businesses generates profit. The fast food industry is that subsector of the economy mostly concentrated by the private sector. Most of these organizations are either owned by individuals, family or franchise. Hence profit on investment is generated.

iv. Customer satisfaction - this is another significant area that micro - fast food outfits tend to achieve. The aim of establishing those outfits is to meet the needs of the people in terms of well prepared food. Thus, every fast food operator is intended to meet the needs of her customers.

Businesses that can be classified under micro fast food group include; soya sellers, akara (fried bean cakes), roasted plantain, roasted corn, Mobil Rice and strew/ jollof rice sellers (Mama put), moin-moin, salad and chicken, pounded-yam, foo - foo/garri, among others, are old ventures of many Nigerian towns providing snacks and quick services for little children to working adults. These can be considered as micro form or small 
scale form of fast food in view of their sizes, since they equally serve the same purpose like the industrial fast food.

Micro - fast food operations is one line of business that keeps going and remains sustainable amidst the current global economic meltdown (Fakokunde, 2010). Micro fast food operations play a key role in the attainment of the goals of national development, which also ensures job opportunities as a fundamental objective of social and economic wellbeing. This is so because, if micro fast food outfits grow, livelihood sources are enhanced while government finances (through taxes) may as well be boosted, which will in turn stimulates the overall qualitative improvement of the economy of the state. Apart from the fact that micro fast food investors or owners benefit from the operation of the businesses in terms of lucrative profits, micro restaurants in the process of decision making will lead to expansion of economic activities in tourism or hospitality subsector of the State. It also has advantages of operational efficiency and service delivery as key to its industry's ability to break even in a highly competitive business setting. It is based on the above premise that this study intends to investigate the contributions of micro fast food outfits operations and economic empowerment of urban dwellers (through income generation) in Calabar urban, Cross River state, Nigeria.

\subsection{Statement of the problem}

Economic wellbeing of the people in most urban areas have become a serious concern as this has not reflected in their social and human condition. The people are still bedevilled with serious neglect and deprivations in terms of their developmental needs and aspirations. The Nigerian government, have at various periods formulated policies and embarked on measures to alleviate the poor standard of living of the people. Such policies as the National Directorate of Employment (NDE), the Green Revolution programme, National Poverty Eradication Programme, National Accelerated Food Production Programme among others. In spite of these efforts, unemployment, underemployment, agricultural stagnation giving rise to food insecurity, poverty etc. are still observed as persistent indicators of failure in enhancing the economic wellbeing of the people (Asamoah, and Chovancova, 2016).

Consequently, it is necessary that activities of micro - fast food outfits be structured and promoted to enable them function effectively to address issues of employment creation and income generation, which will likely have significant impact on the economic wellbeing of the people in Calabar urban and Cross River State at large.

\subsection{Research questions}

The following research questions were pose in the study.

i. Does micro - fast food outfits operations serves as a source of income generation to the people in Calabar urban, Cross River State?

ii. How does micro - fast food outfits operations serve as a source of business empowerment for the people in Calabar urban, Cross River State?

iii. In what way do micro - fast food outfits operations relate with economic wellbeing of the people in Calabar urban, Cross River State in terms of self-sufficiency/ self - reliance?

\subsection{Objectives of the study}

The study seek to investigate micro - fast food outfits operations and the economic empowerment of the people in Calabar urban, Cross River State. The specific objectives are as follows:

i. To investigate how micro - fast food outfits operations in Calabar urban serves as a source of income generation to the people in Calabar urban, Cross River State, Nigeria.

ii. To ascertain whether micro - fast food outfits operations can serve as a source of business empowerment for women in Calabar urban, Cross River State, Nigeria.

iii. To determine how micro - fast food outfits operations relate with economic wellbeing of the people in Calabar urban, Cross River State in terms of self-sufficiency/ self - reliance.

\subsection{Theoretical / Conceptual analysis}

Income generation involves an investment or business activity that focuses on money making. Nzelibe (1996) opined that "income generation takes many forms. Originally, income generation was a term used only by economists to explain the intricacies of a nation's economy. However, it is now quite widely used to cover a range of productive activities by people in the community. Income generation simply means gaining or increasing income', It is all about helping individuals acquire or upgrade skills to enable them earn wages to sustain them and their families. "Human resources are the single most important factor in the economic development of a country. People at or below the poverty line have a negative effect on the total disposable wealth of a country. Income generation seek to address or empower people with knowledge, skills, attitudes and values such that they become positive contributors to their nation's economy' (Emerson, 2009). Mathias and David (2015) maintain that Fast food outfits operations in Nigeria generally are growing at a very high rate. The 
expansion in the industry is influenced by increase in average disposal income of families, close gap between the cost of dinning out and eating at home and tight schedules in lifestyle.

Mehta and Maniam (2002) argued that, people are choosing to spend less time in their kitchens. The number of double-income households is increasing implying that both spouses are working, which creates less time at home and for meal preparations. As a result, consumers purchase more prepared or partially prepared foods that require little or no cooking time and dine out for everyday meals more frequent. As the demand for food away from home increases, there is opportunity for growth in the fast food industry.

Going to a restaurant is a social experience. It offers a chance to interact with friends, enjoy exciting food presentations and be entertained by a small musical ensemble or a chief preparing the meal at the table in front of the customers. Quick meals and convenience, social occasions, business necessity, and celebration are all reasons people dine out (Kivela, 1997).

Ebiringa (2012) opines that Nigeria is currently developing enterprises in agriculture/agro-allied services in areas like foodstuff, restaurant and fast food vending. He further noted that the "National Bureau of Statistics figures (NBS, 2012), revealed that Cross River State contributed 321,658,076.00 Naira to the total consumption of food in fast food, restaurants and canteens in South-South Nigeria, which amounted to 11,960,113,034.16 Naira in 2009/10",

Umeze and Ohen (2014) carried out a study on performance of micro restaurants in Cross River State, Nigeria. The study used data obtained from a random sample of 132 restaurant enterprises and was analysed using descriptive statistics, cost and return analysis. The result of the analysis showed that, the cost of running restaurant business to be very high. Even then, the entrepreneurs still make relatively high profit and returns from it. "An average micro restaurant enterprise makes a net income of $\$ 172,397.63$ per month. Profitability index, rate of return on investment, rate of return on variable cost and operating ratio were found to be $0.26,0.35$, 1.36 and 0.72 respectively, all of which established the fact that restaurant business is profitable in Calabar metropolis, Cross River State. Monthly cost and return analysis revealed that gross margin and net income of a restaurant entrepreneur amounted to $\$ 181,258.97$ and $\$ 172,397.63$ respectively. Age, training received, years of educational training, age of business enterprise, hours spent on the business and total cost of production were among the socioeconomic variables found to have significantly contributed to the total revenue of the entrepreneurs.

Umeze and Ohen (2014) further opined that the informal sector is fundamental to economic development and highly crucial in economic empowerment and poverty alleviation. Thus, confronted with unemployment, high cost of living, many have ventured into micro business sector to earn a living in order to add to their income. Consequently, many fast food restaurants and food outlets are found in metropolitan areas along streets, markets, institutions, residential areas and offices.

\subsection{Theoretical foundation}

In discussing on micro fast food outfits and economic empowerment of urban dwellers in Calabar urban, Cross River State, Nigeria, the economic growth theory was used as a base for the study. The economic growth theory was propounded by Alois Schumpeter in 1911 and was refined in his business cycle in 1942. The economic growth theory focused on those economic policies and programmes which will ensure the rapid growth of the industry and the economy. It is a crucial strategy in generating income earning opportunities for the people through job creation and utilization of abandon asset in the area.

The theory is based on the assumption that if people are empower and enabled to deal with the economic problem confronting them and employment generating activities, it will result in economic growth and diversification of the economy. This will then create opportunity for the people to improve their socio economic condition. According to Schumpeter's economic theory, investment in certain sectors of the economy will create a cumulative expansion throughout the economy. This will in turn result in circular flow, since all economic activities are repetitive in timeless economy. He further maintained that the flow of labour - power and land, flows in every economic period into the satisfaction of wants (Jhingan, 2006).

The theory has implication on this study because, it implies that investment in fast food outfits has the potential to stimulate and create employment opportunities; also generate income which could lead to selfreliance among the people of the State. Based on the theory, fast food outfits can helped to meet up in the satisfaction of wants. Moreover, as it provides avenue for income earning opportunity, it equally serves to sharpen the operators' administrative skills in the management of enterprises, which will also lead to self reliance.

\section{MATERIALS}

\subsection{Settings}

The researchers generated the data for the study from the various fast food outfits located within Calabar urban using a questionnaire. Calabar urban is a combination of two local Governments; Calabar municipal council and 
Calabar South Local Government Area. The two Local Government (Calabar urban) lies between latitude 500 321 and 400221 North and longitude 700501 and 900281 East and is about 21, 481sqkm in size. It is situated within the tropics sharing a common boundary with Odukpani Local Government Area in the North, Akwa Ibom State and Atlantic Ocean in the South and Akpabuyo Local Government Area in the East (National Population Commission, 2006). Calabar urban is moderately undulating with land descending abruptly to Calabar River at the Western boundary, while the slope is towards the Kwa River to the East. The climate of the study area is of the semi-equatorial type with normal heavy downpours. The rainfall is divided into dry and wet season. Rainy season begins in March and ends in November, while the dry season sets in December and ends in February.

The town is the capital of the State, with a population of 375,196 as at 2006 population head count (National Population Commission, 2006). Calabar River which provides sights and images of the Tinapa Business Resort, Calabar Marina, Calabar Residency Museum and the Slave Park are along its course. There are also hotels and fast food businesses of international repute to boost the tourism status of the state. These includes; Crunchies, De choice, Chicken Republic, Chicken Affairs, Peperoni, Chinese Restaurant, Channel View Hotel, Transcorp (Metropolitan) hotel, Mirage Hotel, Mega Hilton Hotels, Marian Hotel, Aqua Vista, Channel View Restaurant, Genny's, Old Chinese Restaurant, Supreme Dishes and a host of others. Micro fast food outfits can be located in every street without stress. Some of these outfits are popularly known as Mama - put, because of their low profile. The town can also be accessed by air through Margaret Ekpo International Airport.

\subsection{Methods}

The study adopted descriptive research design and was limited to the fast food outfits which provides food services to the people in Calabar urban, Cross River State, Nigeria. The population of study covered all micro fast food operators or outfits in Calabar urban. Specifically, the targeted population covered all fast food outfits located in Calabar Municipality and Calabar South Local Government Areas which constitute Calabar Metropolis or urban. Fast food costumers were not used because the problem of the study did not require their responses. The overall respondents for the study was six hundred (600), service providers or fast food outfits, sampled from the two local government areas, using a purposive sampling technique. Since the fast food outfits are spread across Calabar urban, the twelve (12) political wards in Calabar South Local Governments and the ten (10) wards in Calabar Municipality were adopted in selecting the sample, using purposive sampling approach. Because of the variation between the two Local Governments, a uniform sampling was not adopted.

The main instrument for data collection in this study was a structured questionnaire with 20 items questions entitled 'Fast food outfits operations and economic empowerment of urban dwellers' questionnaire'. It consisted of four sections: A, B, C and D. Section A: elicit respondents' demographic information about their personal background such as age, gender, educational level, marital status, and religious affiliation. Section B, C and D: measured on a four - point Likert type scale with 'strongly Agree 'SA', Agree for 'A', Disagree for 'D' and strongly Disagree 'SD'.

The instrument was administered by the researchers to the six hundred (600) respondents in the study area with the help of five research assistants. A formal self-introduction and that of the research assistants was done. Copies of the questionnaire were distributed to the randomly selected respondents for completion. The researchers and the research assistants assisted respondents in explaining difficult items in terms of statement contained in the questionnaire. This method was adopted to ensure accurate response to such items on the questionnaire and to solicit the cooperation of respondents. The data collected from the field were appropriately coded and scored. After the coding of each retrieved instrument, the scores were stored in a data chart.

In order to avoid being bias in the selection of the wards for the study, the researchers, took into consideration the number of wards and the population of each local government, thus, five (5) wards were picked from Calabar Municipality, and six (6) wards from Calabar South Local Government. Eleven (11) political wards were therefore sampled for the study. The names of all the wards in each local government were written in pieces of papers and put separately in two containers. The research assistants were asked to randomly pick from the two containers one each at a time and the name of the Ward selected was used for the study. The micro fast food outfits located in the wards were randomly sampled and a total of 250 respondents from Calabar Municipality and 350 from Calabar South were drawn for the study. Each sampled ward in Calabar Municipality was allocated 50 questionnaire, while those in Calabar South Local Government had 55 each. 
Table 1: Names of political wards in Calabar municipality and Calabar south to be sampled

\begin{tabular}{|l|l|l|}
\hline \multirow{2}{*}{ /N } & Calabar Municipality & Calabar South L.G.A. \\
\cline { 2 - 3 } & Name of ward & Name of ward \\
\hline 1 & Ward 1 & Ward 1 \\
2 & Ward 2 & Ward 2 \\
3 & Ward 3 & Ward 3 \\
4 & Ward 4 & Ward 4 \\
5 & Ward 5 & Ward 5 \\
6 & Ward 6 & Ward 6 \\
7 & Ward 7 & Ward 7 \\
8 & Ward 8 & Ward 8 \\
9 & Ward 9 & Ward 9 \\
10 & Ward 10 & Ward 10 \\
11 & - & Ward 11 \\
12 & - & Ward 12 \\
\hline TOTAL & 10 & 12 \\
\hline
\end{tabular}

\section{Source: NPC 2021 Statistics}

Table 1 above shows the total wards in each local government areas that comprises Calabar urban. Calabar Municipality has ten (10) political wards while Calabar South Local Government has twelve (12) wards.

Table 2: Actual sampled wards

\begin{tabular}{|l|l|l|}
\hline S/N & Calabar Municipality & Calabar South L.G.A. \\
\hline 1. & Ward 1 & Ward 2 \\
4. & Ward 4 & Ward 4 \\
6 & Ward 6 & Ward 7 \\
8. & Ward 8 & Ward 8 \\
9. & Ward 9 & Ward 10 \\
12. & & Ward 12 \\
\hline Total sample wards & 5 & 6 \\
\hline
\end{tabular}

Source: NPC 2021 Statistics

Table 2 above shows that 5 wards and 6 wards were used for the study from the two Local Government. Data were collected, using a well-designed structured questionnaire and simple random sampling technique was adopted in obtaining the sample for the study. The completed questionnaire were collected back and used for analysis. For ease of understanding and since the respondents' demographic characteristics are the same, their data were summarize and presented in a group frequency table below.

Table 3 Socio - Demographic data

\begin{tabular}{|ccc|}
\hline Variables (Age) & No. of respondents & Percentages \\
\hline $18-24$ years & 64 & 10.7 \\
$25-31$ years & 126 & 21 \\
$32-38$ years & 258 & 43 \\
$39-44$ years & 102 & 17 \\
$45-$ years & 50 & 100 \\
\hline TOTAL & 600 & 37 \\
\hline Sex Distribution of Respondents & 63 \\
\hline Male & 220 & 100 \\
\hline Female & 380 & \\
\hline TOTAL & 600 & 30 \\
\hline & Educational level of Respondents & 53.3 \\
\hline Primary education & 180 & 16.7 \\
Secondary education & 320 & 100 \\
Tertiary education & 100 & \\
\hline TOTAL & 600 & 37.5 \\
\hline & Marital status of Respondents & 54.2 \\
\hline Single & 225 & 5.8 \\
Married & 325 & 2.5 \\
\hline Widowed & 35 & 100 \\
\hline Divorced & 15 & \\
\hline TOTAL & 600 & \\
\hline
\end{tabular}

Source: field survey, 2021 
From table 3 above, the respondents' responses on demographic data is indicated. It can be observed on the age category that $64(10.7 \%)$ respondents were between the age brackets of $18-24$ years; $126(21 \%)$ were between the age brackets of 25 - 31 years; 258 (43\%) were of the age brackets of 32 - 38 years; 102 (17\%) respondents were between the age brackets of $39-44$ years, while 50 (8.3percent) were from the age brackets of 45 years and above. From the above description, it means that the greatest number were those between the age brackets of $32-38$ years with $258(43 \%)$ respondents.

With regards to sex, it can also be observed that 220 (37\%) respondents were male, while $380(63 \%)$ respondents were female. From the above description, the female category shared keen interest to the questionnaire items.

On educational level, it was observed that 180 (30\%) respondents had their primary education; $320(53.3 \%)$ respondents had their secondary education, while 100 (16.7\%) respondents had their tertiary education. From the above description, it implies that the greatest number of respondents had secondary education.

With respect to marital status, it can be observed that 225(37.5\%) respondents were single; $325(54.2 \%)$ respondents were married; $35(5.8 \%)$ respondents were widows; while $15(2.5 \%)$ respondents were divorced. From the above indication, it implies that the greatest number of respondents were married with $325(54.2 \%)$ respondents.

\section{Results - Analysis of questions}

\subsection{Research question 1}

Does micro - fast food outfits operations serves as a source of income generation to the people in Calabar urban, Cross River State?

TABLE 4

Respondents' responses on generating income for business owners through fast food outfits operations

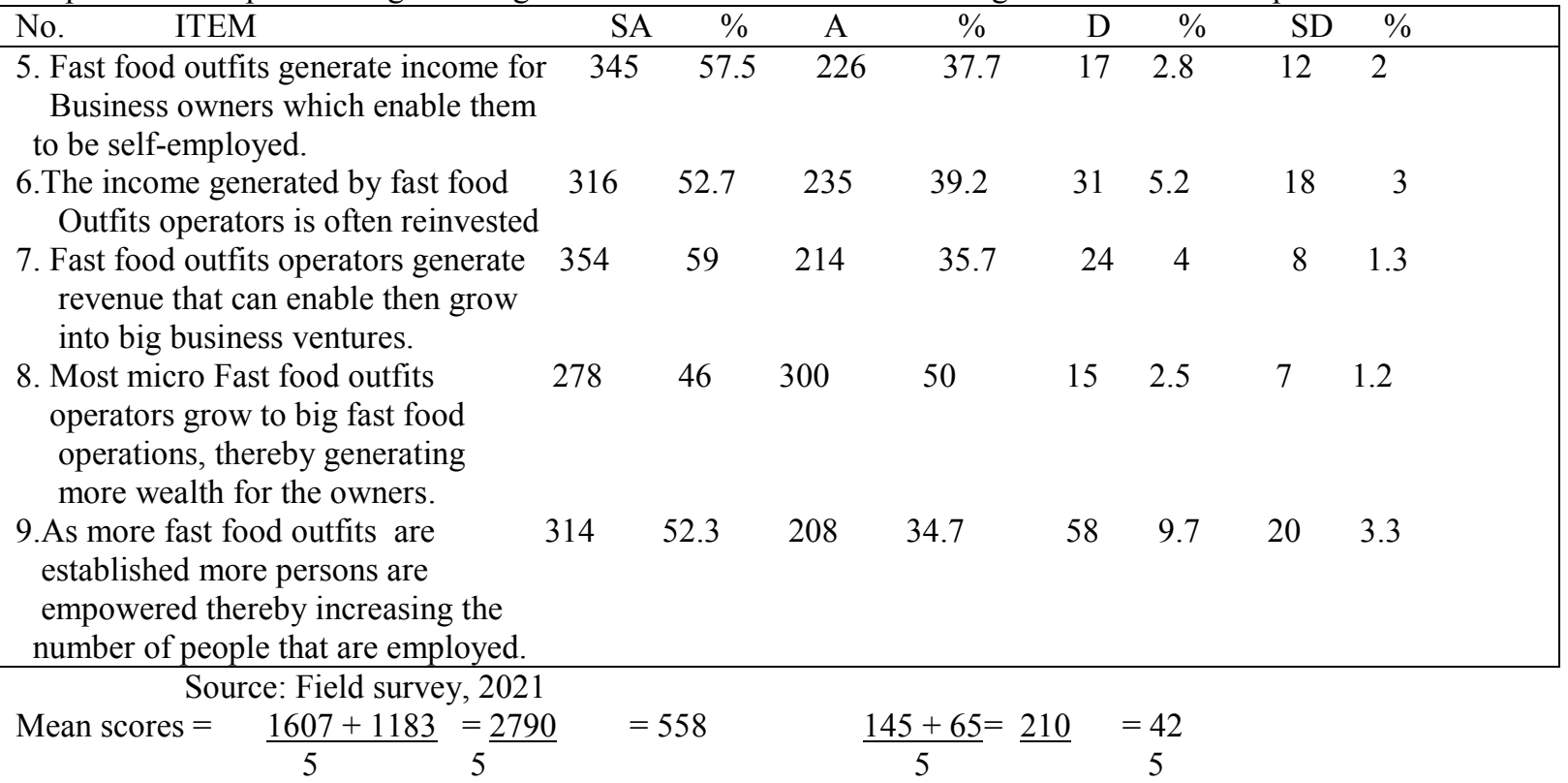

Table 4 above, presents the respondents' responses on generating income for business owners through fast food outfits operations. Responses on question 5 showed that 345 (57.5\%) respondents strongly agreed that Fast food outfits generate income for Business owners which enable them to be self-employed; 226 (37.7\%) respondents agreed, $17(2 . \%)$ respondents disagreed while $12(2 \%)$ respondents strongly disagreed with the statement.

Responses on question 6 indicated that $316(52.7 \%)$ respondents strongly agreed that the income generated by fast food outfits operators is often reinvested, $235(39.2 \%)$ respondents agreed, $31(5.2 \%)$ respondents disagreed while $18(3 \%)$ respondents strongly disagreed with this assertion.

The responses on question 7 showed that 354 (59\%) respondents strongly agreed that Fast food outfits operations generate revenue that can enable them grow into big fast food ventures; 214 (35.7\%) respondents agreed, $24(4 \%)$ respondents disagreed while $8(1.3 \%)$ respondents strongly disagreed with this statement.

Responses on question 8 showed that 278 (46.3\%) respondents strongly agreed that most Micro - Fast food outfits grow to big fast food operations, thereby generating more wealth for the owners, $300(50 \%)$ respondents agreed, $15(25 \%)$ respondents disagreed while $7(1.2 \%)$ respondents strongly disagreed with this statement.

Finally, the responses on question 9 showed that $314(52.3 \%)$ respondents strongly agreed that as more fast food outfits are established more persons are empowered thereby increasing the number of people that are 
employed, $208(34.7 \%)$ respondents agreed, $58(9.7 \%)$ respondents disagreed while $20(3.3 \%)$ respondents strongly disagreed with this assertion. From the above description, it can be concluded therefore that fast food outfits generate income for the business owners and create employment for more people.

The mean (x) scores for those who agreed and disagreed were established. Since the mean of those who agreed (558) is greater than the mean of those who disagree (42), it was concluded that Micro fast food outfits is a source of income generation for business owners.

\subsection{Research question 2}

How does micro - fast food outfits operations serve as a source of business empowerment for the people in Calabar urban, Cross River State?

TABLE 5

Respondents' responses on Micro - Fast Food outfits operations as a source of business empowerment for the people in Calabar urban, Cross River State.

\begin{tabular}{|c|c|c|c|c|c|c|c|c|}
\hline No. $\quad$ ITEM & SA & $\%$ & A & $\%$ & $\mathrm{D}$ & $\%$ & SD & $\%$ \\
\hline $\begin{array}{l}\text { 10. Many people have become } \\
\text { business owners through fast } \\
\text { food outfits operations. }\end{array}$ & 280 & 46.7 & 195 & 32.5 & 84 & 14 & 41 & 6.8 \\
\hline $\begin{array}{l}\text { 11. Those engage in fast food operation } \\
\text { have also acquired good skills and } \\
\text { capacity in managing people and } \\
\text { activities. }\end{array}$ & 315 & 52.5 & 202 & 33 & 53 & 8.8 & 30 & 5 \\
\hline $\begin{array}{l}\text { 12. Many people have adequate } \\
\text { knowledge of business and } \\
\text { management through fast food } \\
\text { outfits operations. }\end{array}$ & 330 & 55 & 218 & 36.3 & 35 & 5.8 & 17 & 2.8 \\
\hline $\begin{array}{l}\text { 13. Fast food operators can generate } \\
\text { Funds to establish other businesses }\end{array}$ & 212 & 35.3 & 328 & 54.7 & 38 & 6.3 & 22 & 3.7 \\
\hline $\begin{array}{l}\text { 14. Employees working in fast } \\
\text { food outfits often acquire } \\
\text { skills in the process of offering } \\
\text { the services to customers. }\end{array}$ & 312 & 52 & 248 & 41.3 & 42 & 7 & 18 & 3 \\
\hline \multicolumn{9}{|l|}{ Source: Field survey, 2021} \\
\hline Mean scores $=\frac{1449+1191}{5}=\underline{2640}$ & \multicolumn{2}{|l|}{$=528$} & \multicolumn{2}{|c|}{$\frac{252+128}{5}$} & \multicolumn{2}{|c|}{$=\frac{380}{5}$} & \multicolumn{2}{|l|}{$=76$} \\
\hline
\end{tabular}

Table 5 above, presents the respondents' responses on Micro - fast food outfits operations as a source of business empowerment for the people in Calabar urban, Cross River State. It can be observed in question 10 that, $280(46.7 \%)$ respondents strongly agreed that many people have become business owners through fast food outfits operations; 195 (32.5\%) respondents agreed; 84 (14 percent) respondents disagreed, while 41 (6.8\%) respondents strongly disagreed with this statement.

Responses on question 11 showed that 315 (52.5\%) respondents strongly agreed that those engage in fast food operations have also acquired good skills and capacity in managing people and activities; 202 (33.7\%) respondents agreed; $53(8.8 \%)$ respondents disagreed, while $30(5 \%)$ respondents strongly disagreed with this assertion.

The responses on question 12 indicated that 330 (55\%) respondents strongly agreed that many people have adequate knowledge of business and management through fast food outfits operations; 218 (36.3\%) respondents agreed; 35 (5.8) disagreed and 17 (2.8 percent) strongly disagreed with this statement.

Responses on question 13 showed that 212 (35.3 percent) respondents strongly agreed that Fast food outfits operations can generate funds to establish another business; 328 (54.7 percent) respondents agreed; 38 (6.3 percent) respondents disagreed, while 22 (3.7 percent) respondents strongly disagreed with the statement.

Finally, the responses on question 14 showed that 312 (52 percent) respondents strongly agreed that Employees working in fast food outfits often acquire skills in the process of offering the services to customers; 248 (41,3 percent) respondents agreed; 42 (7 percent) respondents disagreed, while 18 (3 percent) respondents strongly disagreed with this assertion.

The mean score was calculated. The mean for the acceptance was 528 while the mean score for the disagree was 76. From the above description, it can be concluded that fast food outfit operations is a source of business empowerment for urban dwellers in Calabar, Cross River State, Nigeria. This shows clearly on the positive responses of the respondents to the questionnaire items. 


\subsection{Research question 3}

In what way do micro - fast food outfits operations relate with economic wellbeing of the people in Calabar urban, Cross River State, in terms of self-sufficiency/ self - reliance?

Table 5

Respondents' responses on economic wellbeing of micro fast food outfits' operators in Calabar urban, Cross River State, in terms of self-sufficiency/ self - reliance.

\begin{tabular}{|c|c|c|c|c|c|c|c|c|}
\hline No. $\quad$ ITEM & SA & $\%$ & $\mathrm{~A}$ & $\%$ & & $\%$ & $\mathrm{SI}$ & $\%$ \\
\hline $\begin{array}{l}\text { 15. Micro Fast food outfits has improved } \\
\text { food consumption and quality in } \\
\text { Calabar urban. }\end{array}$ & 315 & 52.5 & 242 & 40.3 & 3 & 5.3 & 11 & 1.8 \\
\hline $\begin{array}{l}\text { 16. Micro fast food outfits has improve the } \\
\text { problem of self-reliance and } \\
\text { self- dependence in Calabar urban. }\end{array}$ & 222 & 37 & 312 & 52 & 42 & 7.0 & 24 & 4.0 \\
\hline $\begin{array}{l}\text { 17. Micro Fast food outfits have been able } \\
\text { to improve the economic } \\
\text { status of disadvantaged members } \\
\text { of Calabar urban through employment } \\
\text { creation and income generation. }\end{array}$ & 326 & 54 & 210 & 35 & 44 & 7.3 & 30 & 5.0 \\
\hline $\begin{array}{l}\text { 18. Most People have acquired } \\
\text { basic skills in fast food management as } \\
\text { a result of operating micro fast food } \\
\text { business. }\end{array}$ & 308 & 51.3 & 214 & 35.7 & 46 & 7.7 & 32 & 5.3 \\
\hline $\begin{array}{l}\text { 19. Micro Fast food outfits has contributed } \\
\text { to improved economic wellbeing of } \\
\text { urban dwellers in Cross River State througl } \\
\text { income generation. }\end{array}$ & gh & 33 & 34 & 58 & 38 & 6.3 & 1 & 2.7 \\
\hline $\begin{array}{l}\text { 20. Micro Fast food outfits generate revenue } \\
\text { the Government of Cross River State throu } \\
\text { payment of taxes. }\end{array}$ & $\begin{array}{l}\text { to } 314 \\
\text { ugh }\end{array}$ & 52.3 & 208 & 34.7 & 58 & 9.7 & 20 & 3.3 \\
\hline \multicolumn{9}{|c|}{ Source: Researcher's field survey, 2021} \\
\hline Mean scores $=\frac{1683+1220}{6}=\underline{2903}$ & $=\underline{484}$ & & & $\frac{+118}{6}$ & & $=\frac{378}{6}$ & $=\underline{63}$ & \\
\hline
\end{tabular}

Table 5 above shows the respondents' responses on the economic wellbeing of Micro fast food outfits operations. Questionnaire item 15 revealed that; 315 (52.5\%) strongly agreed that Micro Fast food outfits has improved food consumption and quality in Calabar urban; 242 (40.3\%) respondents agreed, 32 (5.3\%) disagreed and $11(1.8 \%)$ strongly disagreed.

In questionnaire item 16, $222(37 \%)$ respondents strongly agreed that, Micro fast food outfits has improve the problem of self-reliance and self- dependence in Calabar urban; 312 (52\%) respondents agreed; 42 (7\%) disagreed and 24 (4\%) strongly disagreed.

In question 17, 326 (54\%) respondents strongly agreed that Micro Fast food outfits have been able to improve the economic status of disadvantaged members of Calabar urban through employment creation and income generation, 210 (35\%) respondents agreed; $44(7.3 \%)$ respondents disagreed and $30(5 \%)$ strongly disagreed.

Question 18, was to test whether Most People have acquired basic skills in fast food management as a result of operating micro fast food outfits. 308 (51.3\%) respondents strongly agreed, 214 (35.7\%) agreed, $46(7.7 \%)$ disagreed, and $32(5.3 \%)$ strongly disagreed.

Question 19 seek to investigate whether Micro Fast food outfits has contributed to improved economic wellbeing of urban dwellers in Cross River State through income generation. 198 (33\%) respondents strongly supported the view; 34 (58\%) respondents agreed, $38(6.3 \%)$ disagreed $1(2.7 \%)$ and $1(2.7 \%)$ strongly disagreed.

Finally, question 20 was to ascertain whether Micro Fast food outfits generate revenue for the Government of Cross River State through payment of taxes, 314(52.3\%) respondents strongly agreed, 208 (34.7\%) respondents agreed, $58(9.7 \%)$ disagreed and $20(3.3 \%)$ strongly disagree to the question. The mean scores for the acceptance and rejection were calculated. The agreed was 484 while the disagreed was 63 . Since the agreed is greater than the disagreed, the result shows that micro fast food outfits contribute to the economic wellbeing of urban dwellers in Cross River State, in terms of self - sufficiency/ self - reliance.

\section{Discussion}

This study is intended to investigate micro fast food outfits operation and economic empowerment of urban dwellers (through income generation) in Calabar metropolis, Cross River State, Nigeria. The background of the 
study, the research problem and the research questions were identified to ease the study. The discussion shall be based on the research questions.

\subsection{Research question 1}

Does micro - fast food outfits operations serves as a source of income generation to the people in Calabar urban, Cross River State, Nigeria?

The result for research question one (1) revealed that micro - fast food outfits operations serves as a source of income generation to the people in Calabar urban, Cross River State. The mean (x) scores for those who agreed and disagreed were established. Since the mean of those who agreed (558) is greater than the mean of those who disagree (42), it was concluded that Micro fast food outfits is a source of income generation for business owners in Calabar urban.

The findings is line with Ebiringa (2012) assertion that Cross River State, Micro and small businesses (fast food) are a major source of economic gain to individuals and families. This view was further supported by Ayemi (2015) who noted that operators in the quick service sector popularly known as fast food contribute and record N230 billion into the nation's Gross Domestic Product (GDP) annually. The Nigerian fast food industry is a key contributor to the Nigerian economy, with an estimated annual revenue of N230 billion and taxes in excess of a billion. Though the cost of running restaurant business is very high, the entrepreneurs still make relatively high profit and returns from it (Ayemi, 2015).

\subsection{Research question 2}

How does micro - fast food outfits operations serve as a source of business empowerment for the people in Calabar urban, Cross River State?

The Mean scores for all the respondents who accepted was 558, while those who disagreed was 42 . Since the responses of those who agreed was higher than those who disagreed, it can be concluded that micro - fast food outfits operations serve as a source of business empowerment for the people in Calabar urban, Cross River State. The result collaborated with the views of Olotu and Awoseila (2011) who affirm that fast food outfits and related businesses engage people. This was further stressed by Emerson (2009) that 'fast food outfits has created millions of new jobs at a time when other businesses have been firing workers. It now employs some of the poorest and most disadvantaged members of the society'. Thus, we can conclude from the study that fast food outfits is a source of economic empowerment to the people in Calabar urban, Cross River State, Nigeria.

Research question 3

In what way do micro - fast food outfits operations relate with economic wellbeing of the people in Calabar urban, Cross River State, in terms of self-sufficiency/ self - reliance?

The analysis of the question was carried out and the mean score of the responses for agreed and disagreed calculated. The result shows that, the mean score for those who agreed was 484, while those who disagreed was 63. From the result it can be concluded that, micro - fast food outfits operations relate with economic wellbeing of the people in Calabar urban, Cross River State, in terms of self-sufficiency/ self - reliance. This is in agreement with the view of Ayemi (2015) who asserted that fast food outfits 'collectively provides employment for over 500,000 people at the processing and retailing levels'. That, their activities contribute to a reduction of unemployment, a focal point of the Federal government. This further implies that fast food outfits contribute significantly to the economic wellbeing of the people in Cross River State.

\section{Conclusion}

From the analysis of data, micro fast food outfits has enhanced the socio economic wellbeing of people. It has demonstrated the extent to which private sector is involved in employment creation matters. This has aided in improving the economic wellbeing of people by encouraging self - reliance. The study concluded that the potentiality of revenue mobilization/ income generation through fast food outfits is huge and this affects economic wellbeing of the people positively. Small businesses like fast food outfits are principal avenues for economic empowerment. They generate revenue, create employment for the people, anticipate and manage expectations and demonstrates ability to satisfy the people's needs. This will in turn result in economic empowerment and self-sufficiency/ self - reliance.

\section{Recommendations}

The following recommendations were suggested for implementation.

i). Government should create a favourable business atmosphere for fast food outfits in view of its role as a viable source of employment opportunities. The government could do this by reducing their tax burden.

ii). Micro fast food outfits operations should be motivated through education and enlightenment, so that they will understand their role in economic empowerment.

ii). Soft grants can be provided to micro fast food outfits operators who may not have sufficient capital to invest 
on a large scale fast food outfits.

\section{References}

Asamoah, E.S. \& Chovancova, M. (2016), the theory of consumer behaviour in Fast food marketing: Strategies for competitive advantage, Recent Research in Economics, 51 - 56.

Ayemi, F. (2015), Dimensions of a Relationship Marketing Orientation. Proceedings of the Seventh Biannual World Marketing Congress, Melbourne Australia.

Ebiringa, T. (2012). Perspectives: entrepreneurship development and growth of enterprises in Nigeria. Entrepreneurial Practice Review, 2(2), 1-5.

Emerson, R. W. (2009), Franchise encroachment. American business law Journal, 47 (2), 191-290.

Fakokunde, T. O. (2010), Quality Control and Improvement Practices among Fast Food Retail Outlets in South western Nigeria.

Jhingan, M. L. (2006) the economics of development and planning. India; Vrinda publications ltd.

Kiefer, B. (2002) Farm Management, Planning, Control and Implementation (pp. 154-156). London: McGraw Hill Book Company.

Kivela, J. J. (1997). Restaurant marketing: selection and segmentation in Hong Kong. International Journal of contemporary Hospitality Management, 116-123.

Mackenzie, M., \& Chan, B. (2009) introduction to hospitality. Wan Chai, Hong Kong.

Mathias, A. \& David, B. (2015), the Challenges of Globalization: the Role of the World Bank (pp. 20-23). Paper presented at the Address to the Bundestag, Berlin, Germany. Journal of Agricultural Science Vol. 6, No. 11

Mehta, S. S. \& Maniam, B. (2002). Marketing Determinants of Customers' attitudes towards selecting restaurant. Academy of Marketing Studies Journal, 6, 1-2.

National Bureau of Statistics (NBS). (2012). Consumption Pattern in Nigeria 2009/10. Preliminary Consumption Report (pp. 1-71).

National Population Commission and ICF Macro (2009) Nigeria Demographic and Health Abuja, Nigeria.

Nzelibe, C. G. (1996), entrepreneurship and Management of Small Scale Business, Enugu; Optimal Publisher.

Olotu, O. A., \& Awoseila, F. (2011), reinventing business growth through franchising in developing economies: A study of the Nigerian fast food sector. International journal of Marketing studies, 3(1), p162.

Umeze, M. \& Ohen, C. (2014), Determinants of growth and profitability in small entrepreneurial firms. International Journal of Behaviour and Research, 4(1), 18-27.

The Association of fast food confectioners of Nigeria (2014) The Challenge and Opportunities before the Fast Food Industry: Lagos; AFFCON journal. Vol. 12 (3).

Walker, D. (2011) Business Policy and Strategic Management. Singapore:

Mc-Graw-Hill Books Company.

\section{CONSENT AND ETHICAL APPROVAL}

Approval was sought and granted by the business owners before being engage in the study. The purpose of the study was explained to each respondent and both verbal consent was obtained from respondents prior to the time the questionnaire were to be administered. Confidentiality was ensured by not asking the respondents to write their names on the questionnaire and completed questionnaires were preserved to prevent unauthorized access by people who were not part of the research team.

\section{COMPETING INTERESTS}

Authors have declared that no competing interests exist.

\section{PUBLISHING RIGHTS}

The authors have agreed to grant the editor of this journal approval for the first editing / publishing rights upon acceptance. We wish to state that this work has not been forwarded to another journal for consideration for publication.

This work is original and was carried out in collaboration between the three authors mentioned above. Author Adie, Justine Akunke wrote the protocol, managed the analyses of the study, Author Beshel, I.A. designed the study, carried out the literature searches and performed the statistical analysis and Author Ekpe, Osim James, wrote the first draft of the manuscript. The three authors read and approved the final manuscript for publication. 